\title{
Effects of Cultivar and Explant Sources on Callus Induction and Plant Regeneration in Rice (Oryza sativa
}

\section{L.)}

Hasan Akay and Orhan Kurt

Field Crops Department, Faculty of Agriculture, Ondokuz Mayls University, Samsun 55200, Turkey

\begin{abstract}
In vitro callus induction and plant regeneration potentiality were studied from mature embryo of three Indian rice (Oryza sativa L.) groups at Field Crops Department, Agricultural Faculty, Ondokuz Mayis University, Samsun, Turkey. The study was done by using callus induction MS medium having different concentration of four. The present research was conducted according to the design of randomized blocks trial. A total of 696 calluses, 193 plants and 917 seeds were obtained from Indica group; 2,110 calluses, 103 plants and 235 seeds were obtained from Japonica group; 1,243 calluses and 13 plants were obtained from Javanica group. With regard to number of calluses obtained from each explant source, 52 calluses were obtained from whole-plant explants, 1,668 calluses from root explants, 629 calluses from shoot explants, 649 calluses from the 1 st node explants, 240 calluses from the 2 nd node explants, 269 calluses from the 1 st internode explants and 12 calluses from the 2 nd internode explants. With regard to number of plants obtained from each explant source, 27 plants were obtained from whole-plant explants, 195 plants from shoot explants, 43 plants from the 1st node explants, 40 plants from the 2 nd node explants and four plants from the 1st internode explants. With regard to number of seeds, 823 seeds were obtained from shoot explants and 329 seeds were obtained from the 2nd node explants. Germination rate of harvested seeds was over $90 \%$. The establishment of this regeneration system is essential for the development of a genetic transformation system for commercial rice cultivars.
\end{abstract}

Key words: Rice, Oryza sativa L., callus induction, plant regeneration.

\section{Introduction}

Rice (Oryza sativa L.) is a monocotyledonous plant with the second greatest place with regard to cultivated land and production. It is the basic nutrient source of more than half of the world population [1]. New biotechnological methods have been developed as an alternative to classical plant breeding programs to improve rice yields. These methods are usually complementary or supporting methods to conventional ones [2]. Despite great efforts, desired yield increases have not been achieved yet in rice with conventional farming systems. For sustainable agriculture and quality life, conventional farming systems should be supported with alternative production techniques to have sufficient and quality yields [3].

Corresponding author: Hasan Akay, assistant professor, research fields: field crops, rice.
Plant regeneration from somatic tissue and organs is a significant issue in numerous fields, especially in gene transfer. Thusly, as the results of researches carried out up until now, plant regeneration from somatic tissues has become a routine in several dicotyledonous plants. However, several researches were carried out with various monocotyledonous plants, including rice, for plant regeneration from the root $[4,5]$, mature embryo [4, 6-9], immature embryo $[8,10,11]$, coleoptile $[12,13]$ and young flower organs [7, 14]. But, desired success levels have not been achieved yet.

Callus induction and plant regeneration are influenced by several factors, like nutrient media $[15$, 16], chemical concentrations in nutrient media [7, 17] and plant genotype $[14,18]$. Therefore, there is a need for new and comprehensive researches for healthy and fertile plant regeneration from somatic tissues of 
monocotyledonous plants [19, 20].

From this point forth, the present study was conducted to develop a system for healthy and fertile plant regeneration from various somatic tissues and to integrate the system to be developed into gene transfer studies.

\section{Materials and Methods}

The present research was conducted at Field Crops Department of Ondokuz Mayis University (Samsun, Turkey) in 2008-2009, to develop a system for healthy and fertile plant regeneration from rice somatic tissues. Whole-plant, root, shoot, 1st and 2nd node, 1st and 2nd internode explants of 12-day old rice seedlings belonging to Indica (Pusur, Shoni), Japonica (Taipei-309, Toyonishiki) and Javanica (Aus-38, Baldo) rice groups were used in experiments. The study was conducted in randomized blocks trial design with three replications.

For seedling production from which the explants are to be taken, surface-sterilized seeds were sown in MS0 nutrient media. For surface sterilization, seeds were placed into $100 \mathrm{~mL}$ Erlenmeyer flasks and subjected to pre-treatment in a water bath at $52-57{ }^{\circ} \mathrm{C}$ for $15 \mathrm{~min}$ [21]. Pre-treated seeds were shaken with $70 \%$ ethanol for $1 \mathrm{~min}$, passed through sterile water three times, treated with a couple drops of Tween-20 containing $20 \% \mathrm{NaOCl}$ for $20 \mathrm{~min}$ and passed through sterile water 3-5 times for rinsing. Seeds were then placed in Petri dishes $(9 \mathrm{~cm}$ in diameter) with sterile dry papers to remove the water over the seed surfaces
$[19,20,22,23]$.

Sterilized seeds were sown in MS0 nutrient media, explants were taken from the grown seedlings on the 12th day, explants were then transferred to glass Petri dishes $(15 \mathrm{~cm}$ in diameter for whole-plant explants and $9 \mathrm{~cm}$ for the other explants) with a nutrient media containing $2.5 \mathrm{mg} / \mathrm{L} 2.4-\mathrm{D}, 3 \%$ sugar, $0.76 \%$ agar $(\mathrm{pH}$ $=5.8$ ). Five explants from each explant source were transferred to Petri dishes in three replications. Explants transferred to nutrient media were then kept at $28{ }^{\circ} \mathrm{C}$ in dark incubators until callus induction (Fig. 1). Throughout the incubation period, explants were transferred to fresh LS 2.5 media in every three weeks.

Following the callus induction, calluses were transferred to MS media containing $0.5 \mathrm{mg} / \mathrm{L}$ 6-Benzylaminopurine (BAP) and naftalen asetik asit (NAA), $3 \%$ sugar, $0.76 \%$ agar with $\mathrm{pH}=5.8$. Transferred calluses were subjected to $12 \mathrm{~h}$ light- $12 \mathrm{~h}$ dark photoperiods at $26{ }^{\circ} \mathrm{C}$ in a climate cabin until shoot induction (Fig. 2a).

The shoots formed in nutrient media were then transferred to magenta boxes containing $0.5 \mathrm{mg} / \mathrm{L}$ indole-3-acetic acid (IAA), 3\% sugar, $0.76 \%$ agar with $\mathrm{pH}=5.8$. The magenta boxes with shoots were subjected to $12 \mathrm{~h}$ light-12 $\mathrm{h}$ dark photoperiods at 26 ${ }^{\circ} \mathrm{C}$ in a climate cabin until sufficient root and shoot development (Fig. 2b).

The plantlets with complete root and shoot development were transferred to glass jars with tap water for $1-2 \mathrm{~d}$ to adapt them to external conditions,

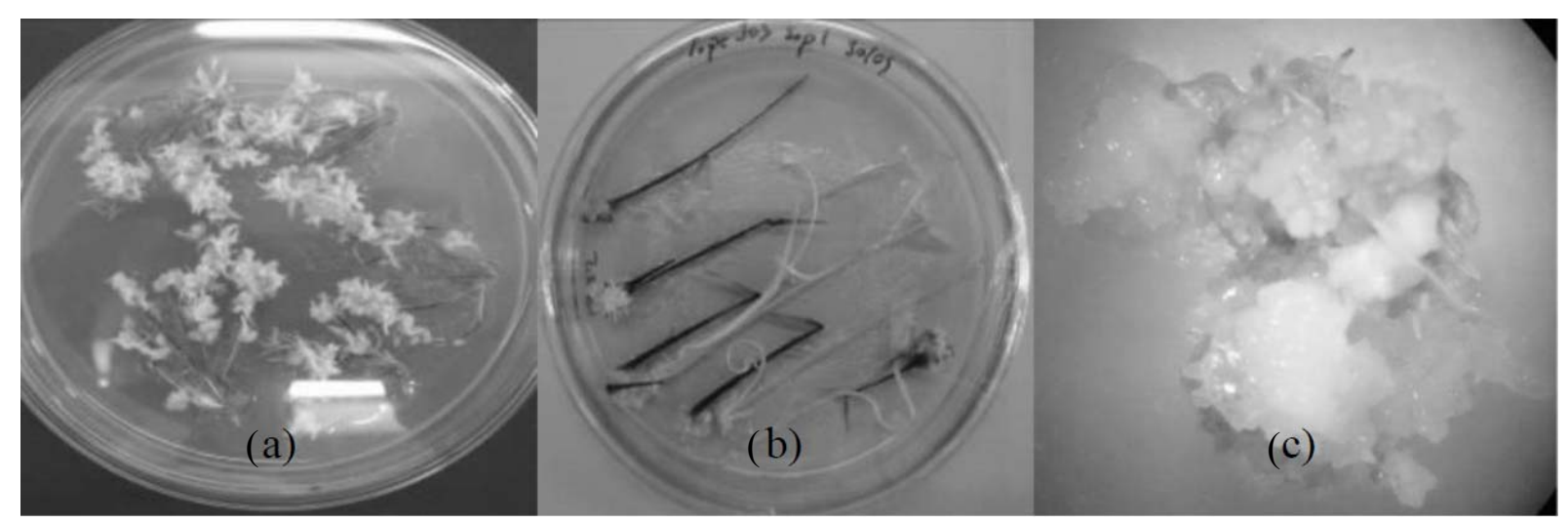

Fig. 1 Root explants (a), stem explants (b) and developing cali general views (c). 


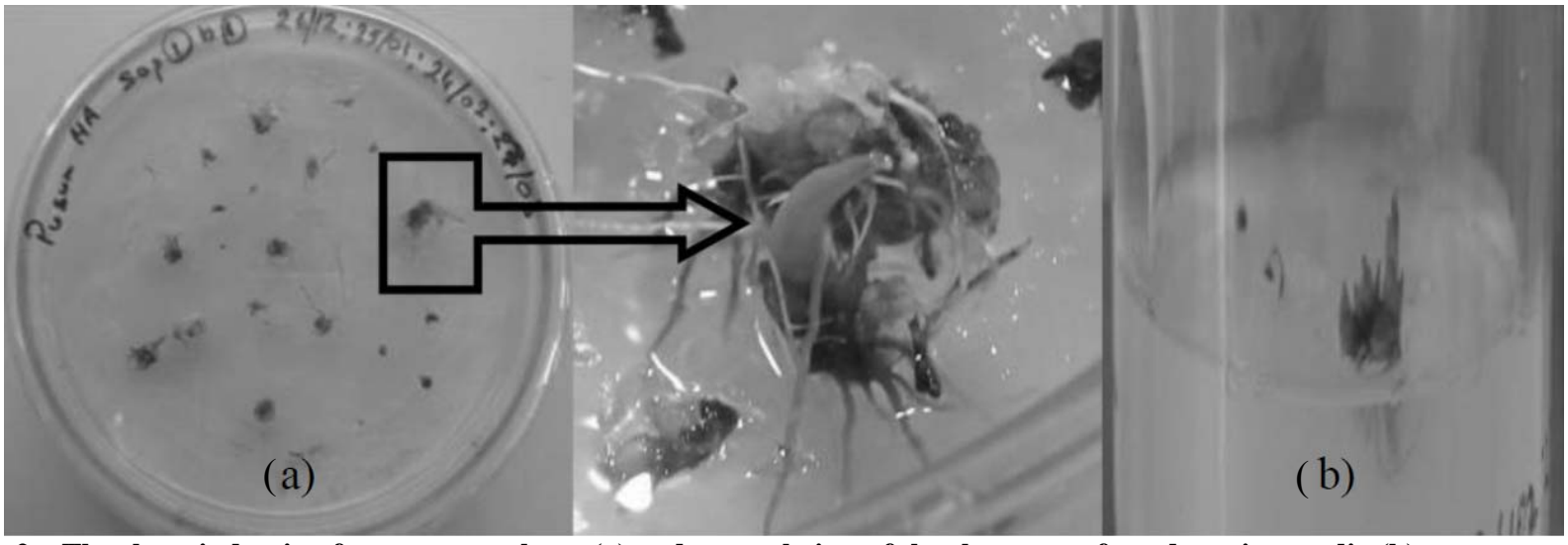

Fig. 2 The shoot induction from stem explants (a) and general view of the shoot transferred rooting media (b).

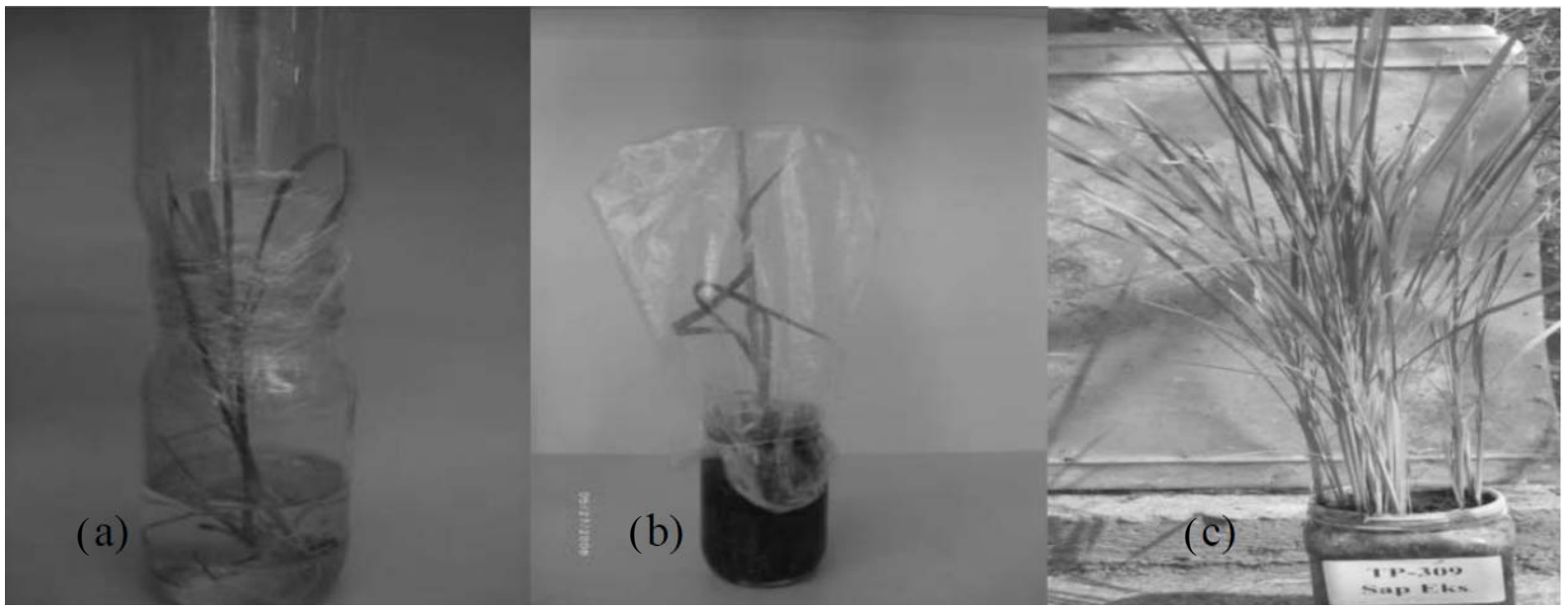

Fig. 3 Plantlets in rooting (a) and compost media (b) and general views of plantlets in panicle formation stage (c).

and jars were covered with polyethylene bags to provide a moisture balance. Two days later, plants were transferred to other glass jars containing 1:1:1:2 yard soil/river sand/perlite/turf mixture, jars were covered again with polyethylene bags to preserve a moisture balance and plants were misted with tap water for $10 \mathrm{~d}$ (Fig. 3a). Two-three weeks later under laboratory conditions, plantlets were transferred to plastic jars (15 cm in diameter) containing clay-loam soil (Fig. 3b). Daily water requirements of the plants were met and yellow leaves were removed. To meet nitrogenous fertilizer need of the plants, $10.75 \mathrm{mg}$ liquid ammonium sulphate was applied to each jar as to have $12 \mathrm{~kg}$ pure substance per decare. Plants developing in plastic jars and with panicles were covered with isolation bags to prevent seed loss, and the plants with physical maturity were manually harvested (Fig. 3c).
The frequency of callus induction and plant regeneration (\%) was measured using Eqs. (1) and (2):

$$
\text { Callus induction }=
$$

(Formed callus number/Total number of explant)

$$
\times 100
$$

Plant regeneration $=$

(Formed number of plant/Total callus number)

$$
\times 100
$$

\section{Results}

\subsection{Number of Callus}

The data obtained from seven different explant sources transferred to nutrient media were provided in Table 1. A total of 4,049 calluses were obtained in nutrient media. With regard to number of calluses from each explant source, 582 calluses were obtained from whole-plant explants, 1,668 calluses from root 
explants, 629 from stem explants, 649 from the 1 st node explants, 240 from the 2nd node explants, 269 from the 1 st internode explants and 12 from the 2nd internode explants. With regard to number of calluses from each rice groups, 696 calluses were obtained from Indica group, 2,110 from Japonica group and 1,243 from Javanica group. With regard to number of calluses from each rice cultivars, 437 calluses were obtained from Pusur and 259 calluses were obtained from Shoni cultivar of Indica group; 733 from Taipei-309 and 1,377 from Toyonishiki cultivar of Japonica group; 720 from Aus-38 and 523 from Baldo cultivar of Javanica group (Table 1, Fig. 4).

\subsection{Number of Plants}

The data on plant regeneration from the calluses transferred to differentiation ambient were provided in Table 1. A total of 309 plants were obtained from these calluses. With regard to number of plants obtained from each explant source, 27 plants were obtained from whole-plant explants, 195 from stem explants, 43 from the 1 st node explants, 40 from the 2nd node explants and four from the 1st internode explants. With regard to number of plants obtained from each rice groups and cultivars, 193 plants were obtained from Indica group, 103 from Japonica group and 13 from Javanica group; 168 plants were obtained from Pusur and 25 from Shoni cultivar of Indica group, 75 from Taipei-309 and 28 from Toyonishiki cultivar of Japonica group, six from Aus-38 and seven from Baldo cultivar of Javanica group (Table 1, Fig. 5).

Table 1 The data obtained from the research of the number of callus, plant and seeds.

\begin{tabular}{|c|c|c|c|c|c|c|c|c|c|c|c|}
\hline \multirow{3}{*}{ Consisted } & \multirow{3}{*}{ Explant sources } & \multicolumn{9}{|c|}{ Group and varieties of rice } & \multirow{3}{*}{$\begin{array}{l}\text { General } \\
\text { total }\end{array}$} \\
\hline & & \multicolumn{3}{|c|}{ Indika } & \multicolumn{3}{|c|}{ Japonica } & \multicolumn{3}{|c|}{ Javanica } & \\
\hline & & Pusur & Shoni & Total & $\mathrm{Tp}$ & Ty & Total & A-38 & Baldo & Total & \\
\hline \multirow{7}{*}{$\begin{array}{l}\text { Numbers } \\
\text { of callus }\end{array}$} & Plant & 13 & 135 & 148 & 96 & 185 & 281 & 105 & 48 & 153 & 582 \\
\hline & Root & 226 & 0 & 226 & 203 & 604 & 807 & 285 & 350 & 635 & 1,668 \\
\hline & Stem & 117 & 36 & 153 & 172 & 203 & 375 & 75 & 26 & 101 & 629 \\
\hline & 1st node & 81 & 65 & 146 & 174 & 210 & 384 & 93 & 26 & 119 & 649 \\
\hline & 2nd node & 0 & 12 & 12 & 76 & 0 & 76 & 79 & 73 & 152 & 240 \\
\hline & 1st internode & 0 & 11 & 11 & 12 & 175 & 187 & 71 & 0 & 71 & 269 \\
\hline & 2nd internode & 0 & 0 & 0 & 0 & 0 & 0 & 12 & 0 & 12 & 12 \\
\hline Total & & 437 & 259 & 696 & 733 & 1,377 & 2,110 & 720 & 523 & 1,243 & 4,049 \\
\hline \multirow{7}{*}{$\begin{array}{l}\text { Numbers of } \\
\text { plants }\end{array}$} & Plant & 10 & 0 & 10 & 10 & 7 & 17 & 0 & 0 & 0 & 27 \\
\hline & Root & 0 & 0 & 0 & 0 & 0 & 0 & 0 & 0 & 0 & 0 \\
\hline & Stem & 136 & 0 & 136 & 46 & 6 & 52 & 6 & 1 & 7 & 195 \\
\hline & 1 st node & 22 & 0 & 22 & 0 & 15 & 15 & 0 & 6 & 6 & 43 \\
\hline & 2nd node & 0 & 25 & 25 & 15 & 0 & 15 & 0 & 0 & 0 & 40 \\
\hline & 1st internode & 0 & 0 & 0 & 4 & 0 & 4 & 0 & 0 & 0 & 4 \\
\hline & 2nd internode & 0 & 0 & 0 & 0 & 0 & 0 & 0 & 0 & 0 & 0 \\
\hline Total & & 168 & 25 & 193 & 75 & 28 & 103 & 6 & 7 & 13 & 309 \\
\hline \multirow{7}{*}{$\begin{array}{l}\text { Number of } \\
\text { seeds }\end{array}$} & Plant & 0 & 0 & 0 & 0 & 0 & 0 & 0 & 0 & 0 & 0 \\
\hline & Root & 0 & 0 & 0 & 0 & 0 & 0 & 0 & 0 & 0 & 0 \\
\hline & Stem & 638 & 0 & 638 & 185 & 0 & 185 & 0 & 0 & 0 & 823 \\
\hline & 1 st node & 0 & 0 & 0 & 0 & 0 & 0 & 0 & 0 & 0 & 0 \\
\hline & 2nd node & 0 & 279 & 279 & 50 & 0 & 50 & 0 & 0 & 0 & 329 \\
\hline & 1st internode & 0 & 0 & 0 & 0 & 0 & 0 & 0 & 0 & 0 & 0 \\
\hline & 2nd internode & 0 & 0 & 0 & 0 & 0 & 0 & 0 & 0 & 0 & 0 \\
\hline Total & & 638 & 279 & 917 & 235 & 0 & 235 & 0 & 0 & 0 & 1,152 \\
\hline
\end{tabular}

$\mathrm{Tp}=$ Taipei-309; Ty = Toyonoshiki; A-38 = Aus-38. 


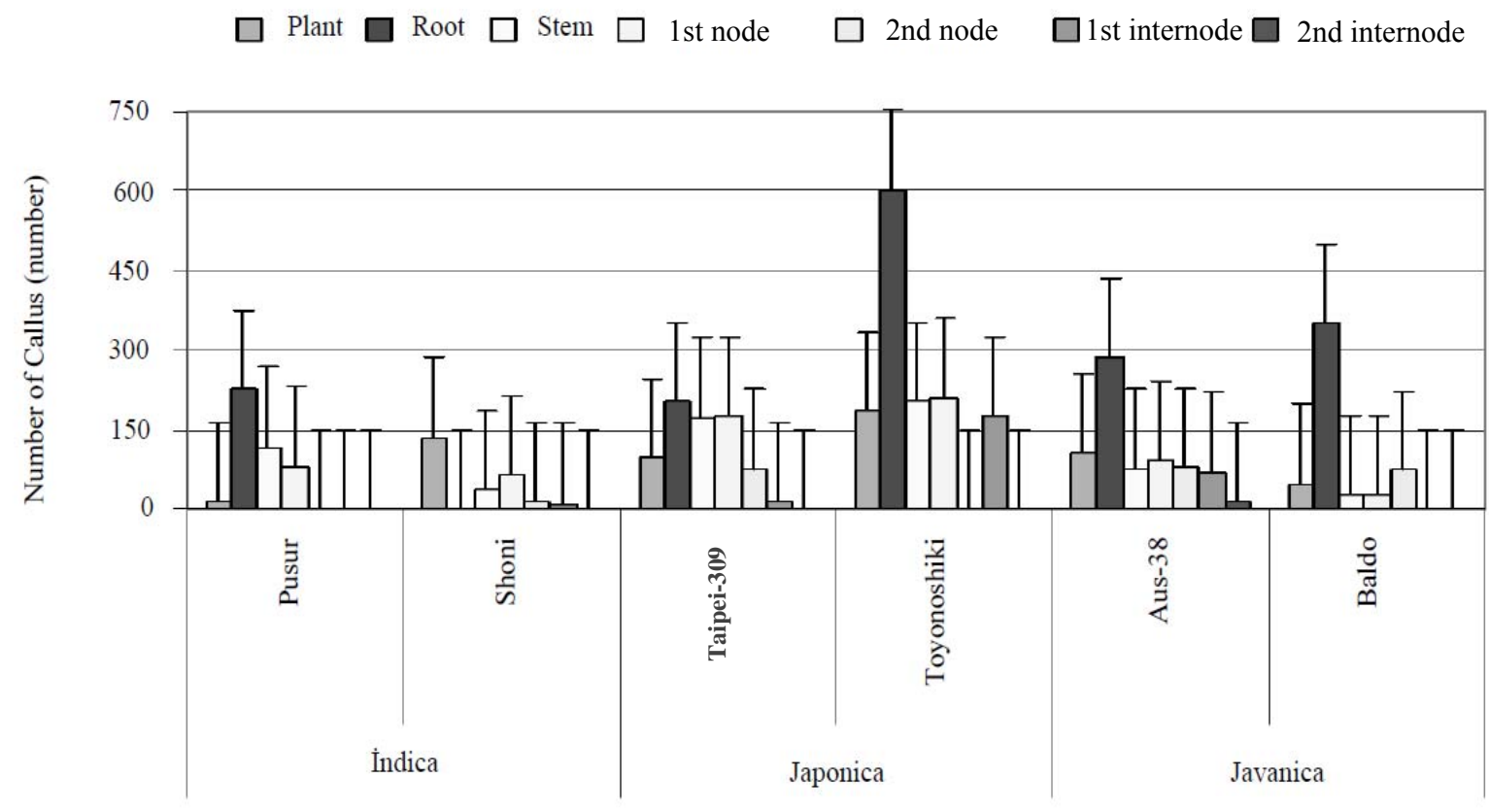

Groups and varieties of rice

Fig. 4 Induction callus varieties and distribution of rice groups.

$\square$ Plant $\square$ Root $\square$ Stem $\square$ 1st node $\square$ 2nd node $\square$ 1st internode $\square$ 2nd internode

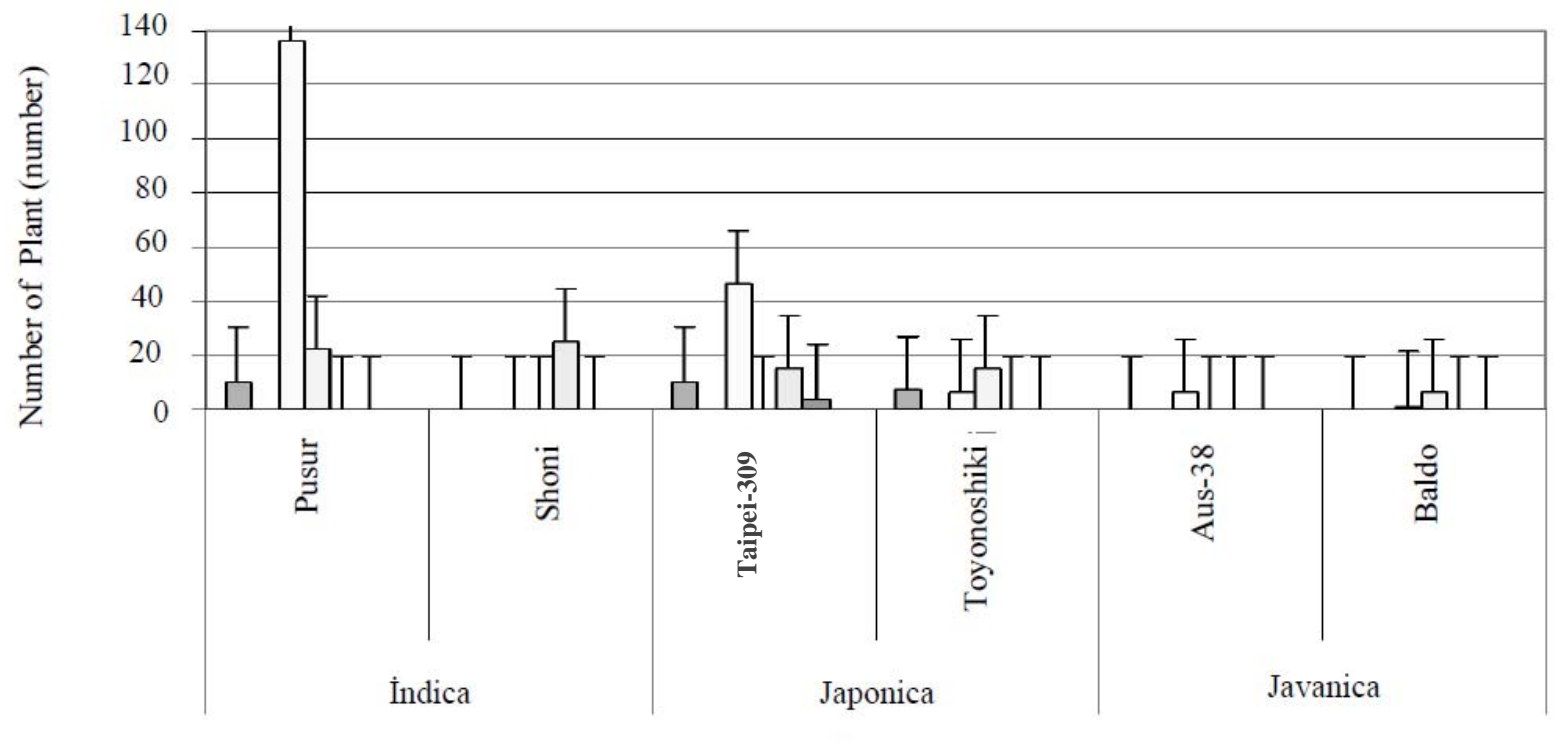

Groups and varieties of rice

Fig. 5 Number of plant varieties and distribution of rice groups.

\subsection{Number of Seeds}

A total of 1,152 seeds were obtained from the harvested plants. With regard to number of seeds obtained from each explant sources, 823 seeds were obtained from shoot explants and 329 seeds were obtained from the 2 nd node explants. With regard to number of seeds obtained from each of rice groups 
and cultivars, 917 seeds were obtained from Indica group and 235 seeds were obtained from Japonica group; 638 seeds were obtained from Pusur, 279 seeds were obtained from Shoni cultivar of Indica group and 235 seeds were obtained from Taipei-309 cultivar of Japonica group (Table 1).

\section{Discussion}

Current findings were parallel to the results of Abe and Sasahara [24], indicating the highest callus induction capability for cultivars of Japonica group. Present findings also comply with the results of Rachmawati and Anzai [25], again indicating the highest callus induction capability for rice cultivars of Japonica group, but do not comply with the findings indicating that this group was followed by Indica and Javanica groups. Such incompliances were mainly because of different cultivars used in these two studies. Thusly, Hoque et al. [26] reported higher callus induction potential for a cultivar of Indica group than for a cultivar of Japonica group. The argument indicating that callus induction potential of the rice did not depend on groups, but resulted from the differences among the genotypes, Kyozuka et al. [27] proved those findings.

Current findings comply with earlier findings indicating that the differences in plant regeneration potential of Indica, Japonica and Javanica rice groups were mainly resulted from the differences among the genotypes rather than the differences among the groups [28], donor plant genotype was a quite significant factor in plant differentiation [29], genotype was more significant in plant differentiation than nutrient media [30].

As to conclude, it can be stated based on current findings that primarily the rice group, then the cultivar and explant source played significant roles in callus induction and plant regeneration from different explant sources. Despite high callus induction rates, plants were not able to be obtained from some explant sources and such a case may be related to explant age, since these explants turned into brown shortly after placing them into differentiation ambient and lost their vigor. Therefore, age of explants transferred to nutrient media can be brought forward (less than $12 \mathrm{~d}$ ), and faster division activity of younger plants may be used as an advantage in differentiation process. Similarly, more efficient callus induction and plant regeneration potential of young explants were also reported by several researchers [12, 22, 31, 32]. Besides the type, amount of plant growth regulator in culture ambient has significant impacts in morphogenesis [33-35]. Such impacts might have also yielded different outcomes in different studies.

The following points were drawn from the present study: (1) present callus induction ambient was a proper ambient; (2) nutrient media should be supplemented with auxin to improve callus stimulation and plant regeneration frequency; (3) explant age should be lower than $12 \mathrm{~d}$; (4) to reduce plant die-outs, roots should be kept in water for 2-3 d while transferring the plants to outside and then plants should be kept in well-moisture balanced ambient for 1-2 weeks.

\section{Conclusions}

In present study, shoot and the 2nd node explants yielded fertile and healthy seeds and plants. In this way, the system desired to be integrated was developed. This system can be integrated into gene transfer studies and may eliminate several problems, especially sterility problem, resulted from long-duration stays under in vitro conditions.

\section{Acknowledgments}

The authors would like to thank the Ondokuz Mayis University (Samsun, Turkey) for their support to the plant biotechnology lab in the field crops section.

\section{References}

[1] FAO. 2009. FAO Statistical Yearbook. Accessed October 20, 2009. www.fao.org. 
[2] Özgen, M., and Türet, M. 1995. "Plant Breeding and Gene Transfer Technology." Presented at the Workshop of Biotechnology and Plant Breeding Notification, 27-36.

[3] Demir, A., Seyis, F., and Kurt, O. 2006. "Genetically Modified Organisms: I. Plants.” Ondokuz Mayıs Uni. J. Agr. Fac. 21 (2): 249-60.

[4] Abe, T., and Futsufara, Y. 1984. "Varietal Difference of Plant Regeneration from Root Callus Tissues in Rice." Japan J. Breed. 34: 147-55.

[5] Mandal, A. B., Maiti, A., and Biswas, A. 2003. "Somatic Embryogenesis in Root Derived Callus of Indica Rice.” $P$. Tis. Cul. 13 (2): 125-33.

[6] Abe, T., and Futsuhara, Y. 1986. "Plant Regeneration from Suspension Cultures of Rice.” Japan J. Breed. 36: 1-6.

[7] Wang, Q., Sun, H., Wang, H., and Wang, X. 1997. "Bioaccumulation of Two Speciations of Rare Earth Elements in Rice Seedlings.” Env. Sci. 18 (6): 56.

[8] Seraj, Z. I., Islam, Z., Faruque, M. O., Devi, T., and Ahmed, S. 1997. "Identification of the Regeneration Potential of Embryo Derived Calluses from Various Indica Rice Varieties." P. Cell Tis. Org. Cul. 48 (1): 9-13.

[9] Azria, D., and Bhalla, P. L. 2000. "Plant Regeneration from Mature Embryo-Derived Calli of Australian Rice (Oryza sativa L.) Varieties." Australian J. Agr. Res. 51 (2): 305-12.

[10] Li, L. F., and Lai, K. L. 1982. "A Comparison of Callus Induction and Plant Regeneration from Young Embryos of Different Rice Varieties." Nat. Sci. Coun. Monthly 10: 135-43.

[11] Koetje, D. S., Grimes, H. D., Wang, Y. C., and Hodges, T. K. 1989. "Regeneration of Indica Rice (Oryza sativa L.) from Primary Callus Derived from Immature Embryos." J. P. Physiol. 135: 184-90.

[12] Oinam, G. S., and Kothari, S. L. 1995. "Totipotency of Coleoptile Tissue in Indica Rice (Oryza sativa L. cv. ch 1039)." P. Cell Rep. 14 (4): 245-8.

[13] Chand, S., and Sahrawat, A. K. 1997. "Somatic Embryogenesis and Plant Regeneration from Coleoptile Tissue of Indica Rice.” Rice Bio. Quarterly 32: 17-8.

[14] Chen, T. H., Lam, L., and Chen, S. C. 1985. "Somatic Embryogenesis and Plant Regeneration from Cultured Young Inflorescences of Oryza sativa L. (Rice)." Plant Cell Tis. Org. Cul. 4: 51-4.

[15] Chen, C. C. 1977. "In Vitro Development of Plant from the Microspores in Rice Tissue Culture." In Vitro 13 (8): 484-9.

[16] Sun, Z. X., and Zheng, K. L. 1990. "Somaclonal Variation in Rice." In Biotechnology in Agriculture and Forestry, edited by Bajaj, Y. P. S. Berlin: Springer-Verlag.

[17] Qu, R. D., and Chen, Y. 1983. “A Preliminary Research on the Function of Enhancement of Callus Induction Frequency." Acta Phy. Sci. 9: 375-81.

[18] Li, W., Ding, C. H., Hu, Z., Lu, W., and Guo, G. Q. 2003. "Relationship between Tissue Culture and Agronomic Traits of Spring Wheat." P. Sci. 164 (6): 1079-85.

[19] Kurt, O. 2007. Gene Transfer in Rice through Choloroplasts. TUBİTAK Project Final Report, Turkey.

[20] Kurt, O., and Akay, H. 2009. "A Research on the Effects of Somatic Origin Explant on Rice (Oryza sativa L.) Callus and Plantlets Formation." Presented at 15th National Biotechnology Congress, 54-9.

[21] Hoshino, S., and Togashi, K. 2000. "Effect of Water-Soaking and Air-Drying on Survival of Aphelenchoides besseyi in Oryza sativa Seeds." J. Nematology 32 (3): 303-8.

[22] Hoque, E. H., and Mansfield, J. W. 2004. "Effect of Genotype and Explant Age on Callus Induction and Subsequent Plant Regeneration from Root-Derived Callus of Indica Rice Genotypes." Plant Cell Tis. Org. Cul. 78: 217-23.

[23] Kurt, O., Aydın, E., and Seyis, F. 2008. "Effects of Different Somatic Explants to Callus Induction and Plant Regeneration in Rice." Res. J. Bio. Sci. 1 (1): 1-3.

[24] Abe, T., and Sasahara, T. 1982. "Variations in Callus Formation from Seeds in Japonica, Indica, Their Hybrids and Large Grain Varieties in Rice.” Japan J. Breed. 32 (1): 53-60.

[25] Rachmawati, D., and Anzai, H. 2006. "Studies on Callus Induction, Plant Regeneration and Transformation of Javanica Rice Cultivars." The Jap. Soc. P. Cell Mol. Bio. 23: 521-4.

[26] Hoque, M. E., Ali, M. S., and Karim, N. H. 2007. "Embryogenic Callus Induction and Regeneration of Elite Bangladeshi Indica Rice Cultivars." Plant Tis. Cul. Bio. 17 (1): 65-70.

[27] Kyozuka, J., Otoo, E., and Shimamoto, K. 1988. "Plant Regeneration from Protoplast of Indica Rice: Genotypic Differences in Culture Response." Theoretical and Applied Genetics 76: 887-90.

[28] Abe, T., Oka, Y., and Sasahara, T. 1994. "Varietal Variations in Biochemical Changes during Growth and Redifferentiation of Rice Callus Cultures." Japan J. Genes 69: 385-96.

[29] Davoyan, E. L. 1987. "Genetic Determination of the Process of Callus Formation and Induction of Regenerates in the Tissue Culture of Rice." Genetika, USSR 23 (2): 303-10.

[30] Mathias, R. J., and Simpson, E. S. 1986. "The Interaction of Genotype and Culture Medium on the Tissue Culture Responses of Wheat (T. Aestivum L. em. Thell) Callus." P. Cell Tis. Org. Cul. 7: 31-7.

[31] Sahrawat, A. K., and Chand, S. 2001. "High-Frequency 


\section{Plant Regeneration in Rice (Oryza sativa L.)}

Plant Regeneration from Coleoptile Tissue of Indica Rice." In Vitro Cel. Dev. Bio. P. 37: 55-61.

[32] Ramesh, M., Murugiah, V., and Gupta, A. K. 2008. "Efficient in Vitro Plant Regeneration via Leaf Base Segments of Indica Rice (Oryza sativa L.)." Ind. J. Ex. Bio. 47: 68-74.

[33] McKinnon, C., Gunderson, G., and Nabors, M. W. 1987. "High Efficiency Plant Regeneration by Somatic Embryogenesis from Callus of Mature Embryo Explants of Bread Wheat (Triticum aestivum L.) and Grain
Sorghum (Sorghum bicolor)." In Vitro Cel. Dev. Bio. 23: 443-8.

[34] Elena, B. E., and Ginzo, H. D. 1988. "Effect of Auxin Levels on Shoot Formation with Different Embryo Tissues from a Cultivar and a Commercial Hybrid of Wheat (Triticum aestivum L.)." Journal P. Phy. 132: 600-3.

[35] Viertel, K., and Hess, D. 1996. "Shoot Tips as an Alternative Source for Regenerable Embryogenic Callus Cultures." P. Cell Tis. Org. Cul. 44: 183-8. 